\title{
Expert Elicitation for Estimation
}

\begin{abstract}
In 2015, the head of the National Authority for Investigation and Prosecution of Economic and Environmental Crime (Økokrim), Trond Eirik Schea, estimated that as many as three out of every four whitecollar criminals went unpunished in Norway. We use a total of seven approaches to estimate the magnitude of white-collar crime. According to our experts, the most likely estimate is 11.9 billion NOK (the average estimate from our seven approaches). Our low estimate of 4.4 billion NOK per year roughly translates into three out of four white-collar criminals getting away every year. This equals Schea's estimate. Our experts, however, claim that there is a 90 percent probability that this figure is too low, and that the problem we are facing is in fact larger.

Keywords Average amount $\bullet$ Estimation approaches $\bullet$ Fraction detected and convicted $\bullet$ Probability distribution $\bullet$ Size of the iceberg - Trond Eirik Schea $\bullet$ Type of crime $\bullet$ Type of offender $\bullet$ US estimates - Uncertainty
\end{abstract}

In 2015, the head of the National Authority for Investigation and Prosecution of Economic and Environmental Crime (Økokrim), Trond Eirik Schea, told the Norwegian newspaper Dagens Neringsliv that probably as many as three out of every four white-collar criminals went unpunished in

P. Gottschalk, L. Gunnesdal, White-Collar Crime in the Shadow Economy, https://doi.org/10.1007/978-3-319-75292-1_4 
Norway. At the same time, he admitted that the probability of getting caught should be larger. How reasonable is Schea's benchmark estimate that only one out of four criminals are caught and brought to justice?

As noted above, we have a total of seven approaches to estimating the magnitude of white-collar crime:

1. Fraction of white-collar criminals that are caught and brought to justice.

2. Fraction with a probability distribution of white-collar criminals that are caught and brought to justice.

3. Fraction of white-collar offender groups that are caught and brought to justice.

4. Fraction of white-collar crime categories that are detected and lead to conviction.

5. Fraction of white-collar crime victim groups that lead to detection and conviction.

6. Fraction of white-collar male and female offenders that are caught and brought to justice.

7. Total magnitude of white-collar crime in billions of NOK.

\section{Fraction of White-Collar Criminals}

We first asked our experts the following question: How large a fraction of all white-collar criminals that commit financial crime in this country do you think are detected and imprisoned? The average answer (excluding the experts with the highest and the lowest estimates) was 9.4 percent or that about one out of ten are caught and sentenced.

To arrive at an estimate of what this implied for the total size of whitecollar crime, we also asked our experts for their opinion on the relative size of the amounts involved in undetected versus detected crimes. If they, for instance, thought that most big-time criminals were indeed among the small proportion of criminals that were caught and convicted, then the size of our iceberg would be relatively small. And conversely, if they thought that the convicted mostly represented relatively small players, then we could have assumed that the size of the iceberg was even larger than the share of convicted criminals would imply.

On average, the experts believe that the undetected criminals represent crimes that are slightly bigger in money terms than detected crimes. 
In other words, they believe the convicted criminals are slightly smaller fish in the sea of crime. Seven out of 15 experts said that above average amounts were probably hidden in legal cases that had not ended in convictions. Three experts argued that there is no difference. Five experts indicated that bigger fish are convicted. On average, the panel of experts is of the opinion that the average amount of money involved is 11.9 percent higher for the 90.6 percent of offenders who are never brought to justice. Our estimate for the total amount of white-collar crime is therefore multiplied by a factor of $1.108(0.094+0.906 \times 1.119)$.

Given our assumptions, 1.1 billion NOK representing 9.4 percent convicted criminals results in an estimated magnitude of 13.4 billion NOK in white-collar crime. This result is computed as follows: 1137 million $\times$ $1.108 \times(100 / 9.4)=13,402$ million NOK.

\section{Fraction with Probability Distribution}

Based on what percentage the experts suggested in question 1 , respondents were faced with nine intervals, where we asked them to place a total of 100 percentage points. When experts were asked for a probability distribution rather than one single percentage, this yielded similar results. The average of all distributions was 10.2 percent detection and conviction. This resulted in an estimate of white-collar crime magnitude of 12.3 billion NOK.

Our respondents varied in the extent to which they wanted to spread their estimate. Two placed all percentage points at one place on the scale as they did not want to indicate uncertainty. Others wanted to spread small probabilities across relatively large intervals. Four experts provided a lower percentage estimate with weighting than without. Two reported the same, and nine experts provided a weighted estimate for the conviction rate that was higher than the initial estimate at question 1 , and thus a smaller iceberg size.

It is certainly difficult to create such a probability distribution, and there were some experts who found this question challenging. Some respondents were not quite aware of how much it affected the weighted estimate to add small probabilities at high percentages. This may have contributed to some experts' weighted estimates being higher than their answer to question 1 , even though they explicitly said during the interview that they thought it was more likely that the percentage was lower than it 
was higher. For example, one expert stated that his choice to estimate 5 percent in question 1 was probably optimistic, and he could well have said 3 percent. Nevertheless, his weighted estimate ended above 7 percent.

Answers that we received to this question can be summarized in Fig. 4.1. The figure illustrates that there are differing opinions among experts concerning the fraction of white-collar criminals that are brought to justice every year.

While the two experts with the highest and lowest weighted estimate were excluded, the remaining panel thought it was most likely that the population convicted ranged between 2.5 percent and 5 percent. The experts also believed that it was equally likely that the population convicted was less than 2.5 percent of the total population of white-collar criminals than that it was above 20 percent. Overall, they thought there was a 65 percent probability that the percentage actually convicted was lower than the average estimate of about 10 percent. As a group, our panel thus believes that it is almost twice as likely that the total amount is greater than the roughly 12 billion NOK they estimated on average, than that the amount is less.

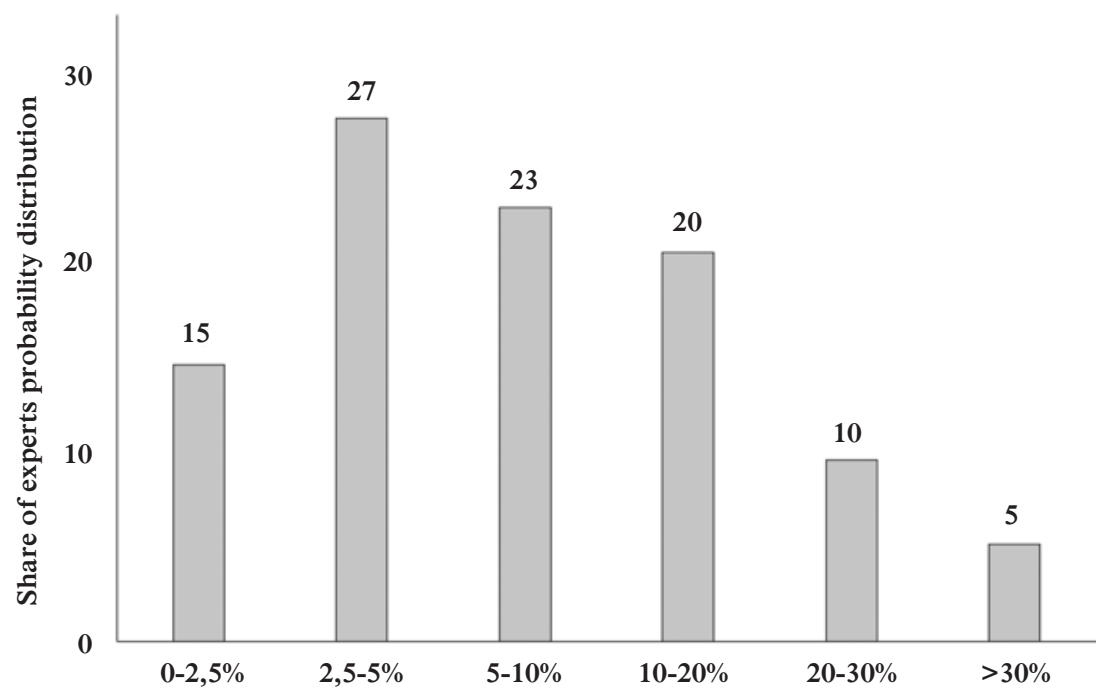

Fig. 4.1 Fraction of white-collar criminals that are brought to justice 
Table 4.1 Estimation based on levels of white-collar criminals

\begin{tabular}{lccccc}
\hline \multirow{2}{*}{$\begin{array}{l}\text { Approach 3: Type of white-collar offender } \\
\text { Figures from our database }\end{array}$} & & \multicolumn{2}{c}{ Expert panel's estimate } \\
\cline { 2 - 3 } \cline { 5 - 6 } $\begin{array}{l}\text { Level of white-collar } \\
\text { criminals }\end{array}$ & $\begin{array}{c}\text { Fraction of } \\
\text { population (\%) }\end{array}$ & $\begin{array}{c}\text { Crime amount } \\
\text { (million NOK) }\end{array}$ & & $\begin{array}{l}\text { Fraction } \\
\text { convicted (\%) }\end{array}$ & $\begin{array}{c}\text { Sum of money } \\
\text { (billion NOK) }\end{array}$ \\
\hline Top level & 28.4 & 33.0 & & 8.5 & 7.1 \\
Middle level & 46.1 & 16.6 & & 10.8 & 4.6 \\
Basic level & 25.5 & 9.7 & & 12.8 & 1.3 \\
Total & 100 & & & & 12.9 \\
\hline
\end{tabular}

\section{Fraction of OfFEnder Groups}

Three levels of offenders were defined in this research: (i) top level offenders such as executives and attorneys, (ii) middle level offenders such as investors and accounting managers, and (iii) basic level offenders such as accounting clerks and carpenters. As listed in Table 4.1, respondents believe the fraction of convictions is lower among top level offenders. This approach resulted in an estimate of white-collar crime being in the magnitude of 12.9 billion NOK.

Respondents indicate in Table 4.1 that the position in the hierarchy of white-collar criminals influences the extent of conviction of white-collar crime. The lowest conviction rate is among the top level criminals who are abusing large sums of money. "Chief financial officers get more easily off the hook, than accountants", one expert said. Several experts said, for example, that very few attorneys are convicted. "Lawyers are very difficult to catch because of confidentiality in the client-attorney relationship, there might have been uncovered much more", another expert said. Yet another expert pointed out that higher up the ladder, an offender is much more capable of covering his or her criminal tracks, and the offender has better access to resources for defense in case of litigation. "Lawyers and CFOs have several tools at their disposal", the expert added.

\section{Fraction of Crime Categories}

Distinction is made between fraud, theft, manipulation, and corruption. As listed in Table 4.2, experts believe theft is most often detected and convicted. Experts believe that corruption most seldom leads to conviction. One reason might be that both parties to the crime- the briber and 
Table 4.2 Estimation based on categories of white-collar crime

\begin{tabular}{lccccc} 
Approach 4: Type of white-collar crime & & & \\
\hline & \multicolumn{3}{c}{ Figures from our database } & & \multicolumn{2}{c}{ Expert panel's estimate } \\
\cline { 2 - 3 } \cline { 5 - 6 } Category of & $\begin{array}{c}\text { Fraction of } \\
\text { population (\%) }\end{array}$ & $\begin{array}{c}\text { Crime amount } \\
\text { (million NOK) }\end{array}$ & & $\begin{array}{l}\text { Fraction } \\
\text { convicted (\%) }\end{array}$ & $\begin{array}{c}\text { Sum of money } \\
\text { (billion NOK) }\end{array}$ \\
\hline Fraud & 42.6 & 25.4 & & 12.4 & 5.6 \\
Theft & 4.2 & 4.8 & & 16.9 & 0.1 \\
Manipulation & 35.3 & 22.8 & & 9.4 & 5.5 \\
Corruption & 17.9 & 2.5 & & 5.7 & 0.5 \\
Total & 100 & & & & 11.8 \\
\hline
\end{tabular}

the bribed-are best served by never disclosing their criminal act. This approach resulted in an estimate of the magnitude of white-collar crime of 11.7 billion NOK.

One expert commented on the low conviction fractions for manipulation and corruption: "There are many blurred lines in manipulation and corruption. I think many people do as they always have done, with the attitude that 'it must surely be okay'. Fraud and theft are much more clearcut, everyone understands that it is wrong. That is why the dark figures are not equally large for those two categories."

\section{Fraction of Victim Groups}

Distinction is made between the following groups of victims: Employers, banks, the tax service, customers, shareholders, and others. As listed in Table 4.3, experts believe bank fraud, tax evasion, and employee fraud achieves a higher conviction rate than customer fraud, insider trading, and cases with other victims. This approach resulted in an estimate of the magnitude of white-collar crime of 10.6 billion NOK.

Several respondents felt that large employers and banks have good control over their capital flows, and that they have the muscle to clean up misconduct cases internally. Rather than "making noise" by reporting their employees to the police, such organizations prefer to offer severance packages to people so that they leave quietly, one respondent said. Many businesses do not like to lose face, another said: "Many companies have no desire to end up on a newspaper front page telling they have unfaithful servants in their ranks.” 
Table 4.3 Estimation based on categories of white-collar crime victims

\begin{tabular}{|c|c|c|c|c|}
\hline \multirow[b]{2}{*}{$\begin{array}{l}\text { Category of white- } \\
\text { collar crime victim }\end{array}$} & \multicolumn{2}{|c|}{ Figures from our database } & \multicolumn{2}{|c|}{ Expert panel's estimate } \\
\hline & $\begin{array}{l}\text { Fraction of } \\
\text { population (\%) }\end{array}$ & $\begin{array}{l}\text { Crime amount } \\
\text { (million NOK) }\end{array}$ & $\begin{array}{l}\text { Fraction } \\
\text { convicted (\%) }\end{array}$ & $\begin{array}{l}\text { Sum of money } \\
\text { (billion NOK) }\end{array}$ \\
\hline Employers & 27.9 & 8.7 & 13.4 & 1.2 \\
\hline Banks & 14.2 & 49.5 & 14.9 & 3.0 \\
\hline Tax authority & 22.1 & 18.0 & 14.2 & 1.9 \\
\hline Customers & 16.4 & 17.3 & 8.6 & 2.1 \\
\hline Shareholders & 7.4 & 29.8 & 8.2 & 1.7 \\
\hline Others & 12.0 & 6.9 & 8.6 & 0.6 \\
\hline Total & 100 & & & 10.6 \\
\hline
\end{tabular}

\section{Gender Fractions}

Only 7.6 percent of convicted white-collar criminals in Norway are women, while 92.4 percent are men. Perhaps the rate of detection and conviction is dependent on gender. Our experts think so, as shown in Table 4.4, where respondents believe that only 6.5 percent of female white-collar criminals are caught and brought to justice. This approach resulted in an estimate of the magnitude of white-collar crime of 12.2 billion NOK.

The average man's crime amount is more than twice as large as for female offenders. One explanation for this difference, experts said, is owing to the difference in positions held by men and women in organizations. "Men are often in key positions, and closer to the money", one expert said. Several experts gave the impression that it is "easier" to be a female criminal, because females get away with it more easily, since they are not suspected of crime. "If it becomes a criminal case, women are more likely to be convicted, but female crime seldom becomes a criminal case", another respondent said. Yet another respondent pointed out that women often participate as facilitators, and also "understand what is going on", but are not necessarily convicted with the men involved. Even when both men and women are involved in financial crime, prosecutors may find it expedient to reduce the case so that men are prosecuted, while women are dismissed from the case. Sometimes, women are perceived as victims, even when they are active facilitators in the crime. 
Table 4.4 Estimation based on gender of white-collar criminals

Approach 6: Gender of white-collar criminal

\begin{tabular}{lcclcc}
\hline & \multicolumn{2}{c}{ Figures from our database } & & \multicolumn{2}{c}{ Expert panel's estimate } \\
\cline { 2 - 3 } \cline { 5 - 6 } $\begin{array}{l}\text { Category of white- } \\
\text { collar crime victim }\end{array}$ & $\begin{array}{l}\text { Fraction of } \\
\text { population (\%) }\end{array}$ & $\begin{array}{c}\text { Crime amount } \\
\text { (million NOK) }\end{array}$ & $\begin{array}{l}\text { Fraction } \\
\text { convicted (\%) }\end{array}$ & $\begin{array}{l}\text { Sum of money } \\
\text { (billion NOK) }\end{array}$ \\
\hline Women & 7.6 & 9.0 & & 6.5 & 0.7 \\
Men & 92.4 & 20.4 & & 10.5 & 11.5 \\
Total & 100 & & & & $\mathbf{1 2 . 2}$ \\
\hline
\end{tabular}

\section{Total Crime Magnitude}

The final estimation technique in this research was to ask experts for their outright estimate of the total magnitude of white-collar crime in billions of NOK. The average response was 10.1 billion NOK.

Some of the respondents described their responses as "think of a number", and three experts declined to provide a number. However, most of the respondents both justified and reasoned their way to an answer, partly based on other estimates recorded for various types of economic crime. Two experts submitted answers that they directly connected to their previous percentage-based estimates. This worked fine for one of the experts, but not for the other one whose estimate of the money amount was far below what he had indicated for his conviction fraction.

During interviews, several respondents found it problematic to define limits for an estimate. For example, one expert-who incidentally had the highest estimate of the total magnitude of white-collar crime-said that he included "the organized part of social security fraud" in his estimate.

\section{All Approaches Combined}

Table 4.5 summarizes all seven approaches that resulted in an overall average of 11.9 billion NOK in white-collar crime damage annually in Norway. It varies from 10.1 billion NOK to 13.4 billion NOK.

Figure 4.2 visualizes the numbers in Table 4.5. The overall average of 11.9 billion NOK is illustrated by the last bar. 
Table 4.5 Estimation based on seven approaches

\begin{tabular}{cc}
\hline All approaches combined & \\
\hline Approach & Expert elicitation (billion NOK) \\
\hline $\mathbf{1}$ & 13.4 \\
2 & 12.3 \\
$\mathbf{3}$ & 12.9 \\
$\mathbf{4}$ & 11.8 \\
$\mathbf{5}$ & 10.6 \\
$\mathbf{6}$ & 12.2 \\
7 & 10.1 \\
Average & 11.9
\end{tabular}

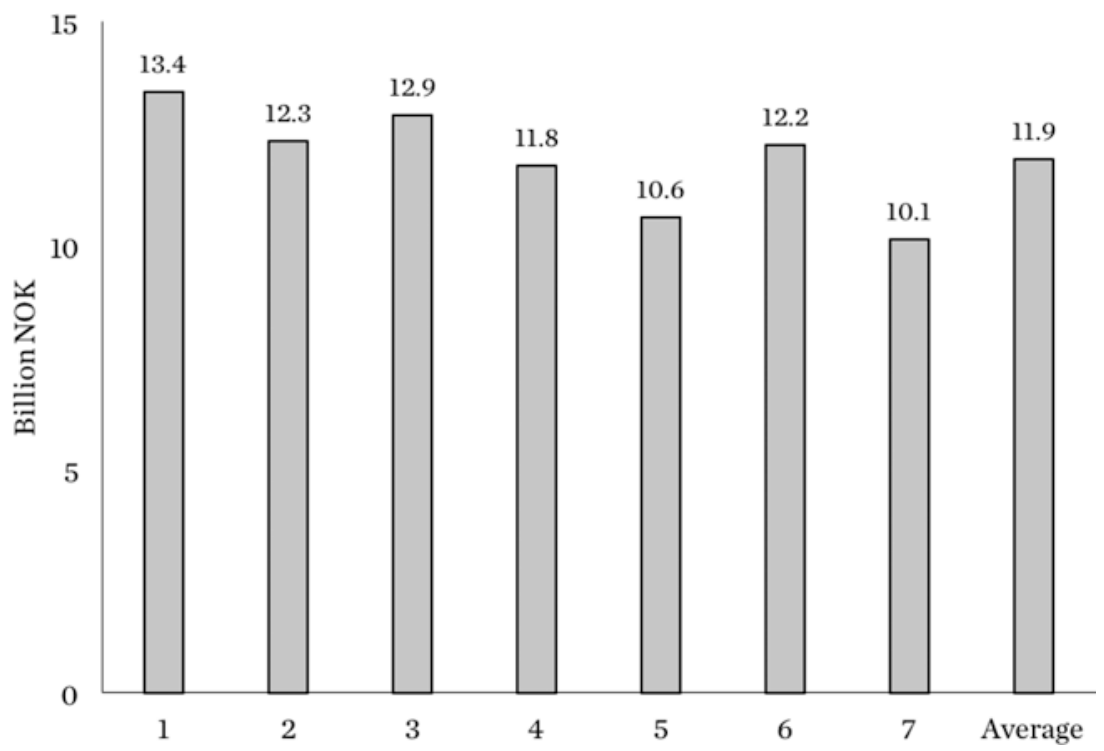

Fig. 4.2 Estimation of white-collar crime based on seven approaches

So far, we have presented research results in terms of average numbers for percentages, and millions and billions of NOK. Of course, there were substantial deviations in answers, both among experts and for each expert when indicating her or his own uncertainty. By combining our experts' probability distributions in approach 2 above, we are able to compute a probability distribution. Table 4.6 consists of four elements: (i) the visible 
Table 4.6 Lower and upper bounds for the estimate of white-collar crime

Variation in estimates

White-collar crime (billion NOK)

Detected crime

1.1

Low estimate

4.4

Main estimate

11.9

High estimate

56.8

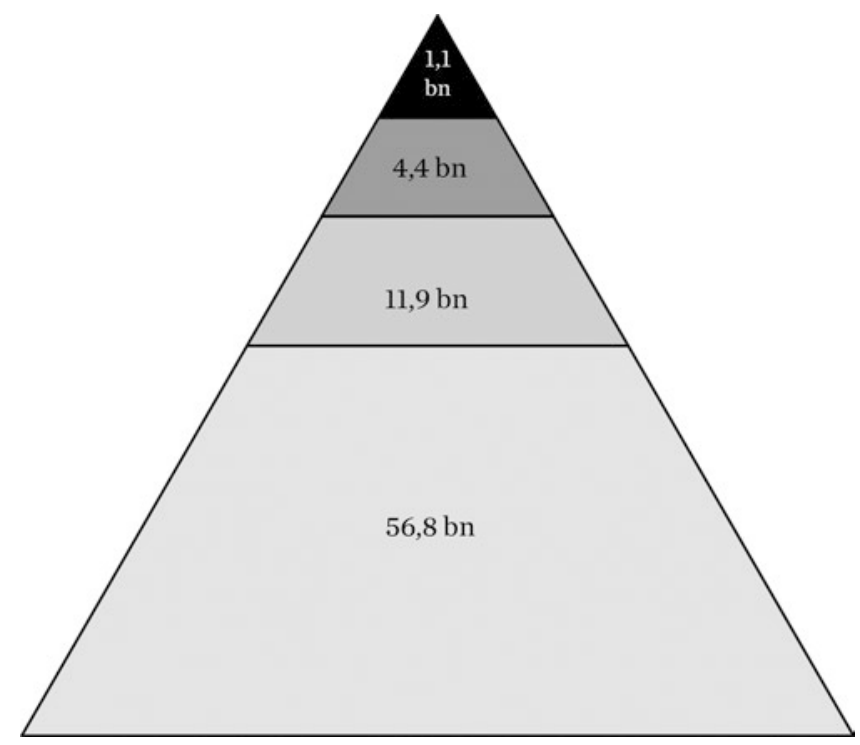

Fig. 4.3 Tip of the iceberg for white-collar crime

part of the iceberg, 1.1 billion NOK, (ii) the very optimistic low estimate of 4.4 billion NOK (less than 10 percent likely that the actual amount is lower, according to our experts), (iii) the most likely estimate of 11.9 billion NOK (the average estimate from our seven approaches), and (iv) the very pessimistic high estimate of 56.8 billion NOK (less than 10 percent likely that the actual amount is higher, according to our experts).

Figure 4.3 illustrates the uncertainty based on the numbers in Table 4.6. Later in the book we will compare these estimates to similar estimates made for social security fraud. 
Our low estimate of 4.4 billion NOK per year roughly translates into three out of four white-collar criminals getting away every year. As we saw above, this equals Økokrim-boss Trond Eirik Schea's estimate from 2015. Our experts, however, claim that there is a 90 percent probability of this figure being too low, and that the problem we are facing is in fact larger.

\section{COMparison With US Estimates}

In comparison to the United States, 11.9 billion NOK is modest not only in comparison to the $40-80$ billion NOK based on estimates from the US National White Collar Crime Center (also known as NW3C) (Huff et al. 2010), but also in comparison to the equivalent of 120 billion NOK suggested by the Association of Certified Fraud Examiners (ACFE 2008, $2014,2016)$ published in 2016.

With a population of 5 million inhabitants in Norway as compared to the United States' 321 million inhabitants, the equivalent of $\$ 1.5$ billion detected in Norway would be $\$ 96$ billion in the United States. Ninety-six billion dollars is less than estimates from the Federal Bureau of Intelligence (FBI) and the Association of Certified Fraud Examiners, that approximate the annual cost of white-collar crime as being between $\$ 300$ and $\$ 600$ billion, according to NW3C (Huff et al. 2010).

NW3C estimates, in a report by Huff et al. (2010), the scope of whitecollar crime in the United States at between 300 and 660 billion dollars. Given that the United States has a population of 321 million compared to 5 million in Norway, the equivalent range for Norway would be from 5 to 10 billion US dollars, if we assume that white-collar crime has the same prevalence in both nations. This interval in NOK is between 40 billion and 80 billion. Therefore, it is not inconceivable that our estimated amount (11.9 billion NOK) is conservative, and that the high estimate in Table 4.6 of 56.8 billion is not entirely unlikely.

In the United States, NW3C's mission is to provide a national support system for agencies involved in the prevention, investigation, and prosecution of economic crime and to support and partner with other appropriate entities in addressing security initiatives, as they relate to financial crime (www.nw3c.org). 


\section{REFERENCES}

ACFE. (2008). 2008 Report to the Nation - On Occupational Frand \& Abuse. Austin: Association of Certified Fraud Examiners.

ACFE. (2014). Report to the Nations on Occupational Frand and Abuse, 2014 Global Fraud Study. Austin: Association of Certified Fraud Examiners.

ACFE. (2016). CFE Code of Professional Standard. Association of Certified Fraud Examiners. www.acfe.com/standards/

Huff, R., Desilets, K., \& Kane, J. (2010). The National Public Survey on White Cllar Crime. Fairmont: National White Collar Crime Center. www.nw3c.org.

Open Access This chapter is licensed under the terms of the Creative Commons Attribution 4.0 International License (http://creativecommons.org/licenses/ by $/ 4.0 /)$, which permits use, sharing, adaptation, distribution and reproduction in any medium or format, as long as you give appropriate credit to the original author(s) and the source, provide a link to the Creative Commons license and indicate if changes were made.

The images or other third party material in this chapter are included in the chapter's Creative Commons license, unless indicated otherwise in a credit line to the material. If material is not included in the chapter's Creative Commons license and your intended use is not permitted by statutory regulation or exceeds the permitted use, you will need to obtain permission directly from the copyright holder.

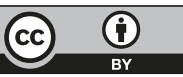

